\title{
Large carnivore impacts are context-dependent
}

Haswell, P.M.; Kusak, Josip; Hayward, M.W.

\section{Food Webs}

DOI:

10.1016/j.fooweb.2016.02.005

Published: 01/09/2017

Peer reviewed version

Cyswllt i'r cyhoeddiad / Link to publication

Dyfyniad o'r fersiwn a gyhoeddwyd / Citation for published version (APA):

Haswell, P. M., Kusak, J., \& Hayward, M. W. (2017). Large carnivore impacts are contextdependent. Food Webs, 12, 3-13. https://doi.org/10.1016/j.fooweb.2016.02.005

\footnotetext{
Hawliau Cyffredinol / General rights

Copyright and moral rights for the publications made accessible in the public portal are retained by the authors and/or other copyright owners and it is a condition of accessing publications that users recognise and abide by the legal requirements associated with these rights.

- Users may download and print one copy of any publication from the public portal for the purpose of private study or research.

- You may not further distribute the material or use it for any profit-making activity or commercial gain

- You may freely distribute the URL identifying the publication in the public portal ?
}

Take down policy

If you believe that this document breaches copyright please contact us providing details, and we will remove access to the work immediately and investigate your claim. 
Haswell PM, Kusak J, Hayward MW (2017) Large carnivore impacts are context-dependent. Food Webs 12:3-13. doi: 10.1016/j.fooweb.2016.02.005

Article history:

Received 24 September 2015

Received in revised form 7 January 2016

Accepted 9 February 2016

Available online 6 March 2016

$\underline{\text { Large Carnivore impacts are context-dependent }}$

Peter M. Haswell ${ }^{\text {ab }}$, Josip Kusak ${ }^{\mathrm{c}}$, Matt W. Hayward ${ }^{\text {adef }}$

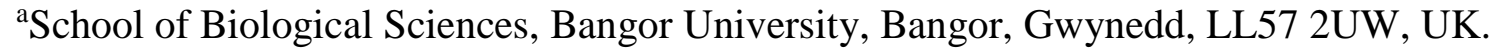

${ }^{\mathrm{b}} \mathrm{UK}$ Wolf Conservation Trust, Butlers Farm, Beenham, Berkshire, RG7 5NT

${ }^{\mathrm{c}}$ Department of Biology, Veterinary Faculty, University of Zagreb, Heinzelova 55, 10000, Zagreb, Croatia

${ }^{\mathrm{d}}$ School of Environment Natural Resources and Geography, Bangor University, Bangor, Gwynedd, LL57 2UW, UK.

${ }^{\mathrm{e}}$ Centre for African Conservation Ecology, Nelson Mandela Metropolitan University, Port Elizabeth, South Africa

${ }^{\mathrm{f}}$ Centre for Wildlife Management, University of Pretoria, South Africa.

Corresponding author: Peter M. Haswell, p.m.haswell@bangor.ac.uk

\section{Keywords}

Landscape of fear; interspecific competition; apex predator; large carnivore; mesopredator release hypothesis; predation risk.

\section{Abstract}

Interactions between large carnivores and other species may be responsible for impacts that are disproportionately large relative to their density. Context-dependent interactions between species are common but often poorly described. Caution must be expressed in seeing apex predators as ecological saviours because ecosystem services may not universally apply, particularly if inhibited by anthropogenic activity. This review examines how the impacts of large carnivores are affected by four major contexts (species assemblage, environmental productivity, landscape, predation risk) and the potential for human interference to affect these contexts. Humans are the most dominant landscape and resource user on the planet and our management intervention affects species composition, resource availability, demography, behaviour and interspecific trophic dynamics. Humans can impact large carnivores in much the same way these apex predators impact mesopredators and prey species - through densitymediated (consumptive) and trait/behaviourally-mediated (non-consumptive) pathways. Mesopredator and large herbivore suppression or release, intraguild competition and predation pressure may all be affected by human context. The aim of restoring 'natural' systems is somewhat problematic and not always pragmatic. Interspecific interactions are 
influenced by context, and humans are often the dominant driver in forming context. If management and conservation goals are to be achieved then it is pivotal to understand how humans influence trophic interactions and how trophic interactions are affected by context. Trade-offs and management interventions can only be implemented successfully if the intricacies of food webs are properly understood.

\section{Introduction}

When understanding and managing trophic dynamics, what is deemed a natural or unnatural interaction must first be considered (Rolston 2001). The aim of restoring 'natural' systems in the modern era becomes somewhat problematic. Wildlife conservation is still possible in human dominated landscapes but maintaining top-down ecological processes in such landscapes is challenging (Chapron et al. 2014; Linnell et al. 2015; López-Bao et al. 2015). The impacts of world-wide predator decline and the relative importance of direct and indirect species interactions have been highlighted as fundamental ecological questions (Sutherland et al. 2013). Yet caution has been expressed in seeing apex predators like the grey wolf Carnivora Canidae Canis lupus as ecological saviours because ecosystem services may not universally apply, particularly if inhibited by anthropogenic activity (Mech 2012). Furthermore, there is only one intact terrestrial predator guild in the world (Africa), so all other guilds may reflect the impacts of the Pleistocene megafauna extinctions and shifting baselines to mesopredator-dominated systems (Fleming et al. 2012; Valkenburgh et al. 2015). The question arises as to what the conservation benchmark or baseline is, was or should be given a particular ecological context (Berger 2008; Hayward 2009; Hayward 2012).

Species at higher trophic levels are often lost more rapidly than those at lower trophic levels (Dobson et al. 2006). Apex predator decline and trophic simplification is something of great concern worldwide (Estes et al. 2011; Johnson 2010; Ripple et al. 2014). It is imperative to understand the interactions and potential impacts of apex predators because their absence or decline can have undesired effects (Berger et al. 2008; Jackson et al. 2001; Terborgh et al. 2001). The consequences of upper trophic level decline and the loss of ecosystem services provided by large carnivores could lead to environmental degradation through the release of top-down control upon herbivores (Beschta and Ripple 2012; Hebblewhite et al. 2005; Ripple and Larsen 2000) and mesopredators (Newsome and Ripple 2014; Prugh et al. 2009; Ritchie and Johnson 2009). If healthy populations of top predators can be maintained within ecosystems, they should also contain healthy communities and populations of the many species that perform a diversity of ecosystem services at lower trophic levels (Dobson et al. 2006).

As the most dominant landscape user and primary resource consumer on the planet (Paquet and Darimont 2010), humans greatly modify the landscapes and communities that apex predators interact with through a myriad of disturbance types (Blanc et al. 2006; Frid and Dill 2002; Sibbald et al. 2011). The positive (Kilgo et al. 1998; Kloppers et al. 2005; Leighton et al. 2010) or negative (Hebblewhite et al. 2005; Jayakody et al. 2008; Pelletier 2006) nature of this disturbance however depends entirely on management perspective (Reimoser 2003). Humans can impact apex predators in much the same way as they impact smaller predators 
and prey species, through density-mediated (consumptive) and trait/behaviourally-mediated (non-consumptive) pathways (Ordiz et al. 2013). Impacts can be direct (Packer et al. 2009; Virgos and Travaini 2005) or indirect through effects on other species or habitat (Rogala et al. 2011; Sidorovich et al. 2003).

Context-dependent interactions between species are common but often poorly described (Chamberlain et al. 2014). This review examines the contextual impacts of large carnivores and the potential for human interference through effects on species assemblage, environmental productivity, landscape and predation risk (Fig.1 and Table 1). If we are to predict the consequences of predator management, it is critical to understand the dynamics of interspecific relationships between organisms (Elmhagen et al. 2010; Prugh et al. 2009; Ripple et al. 2014) and to determine if this context can be manipulated to achieve management and ecosystem service goals (Kareiva et al. 2007).

A search of literature was conducted using Web of Science and Google Scholar with "OR" and "AND" search operators and a mixture of key words (apex predator*, large carnivore*, carnivore*, mesopredator release, mesopredator*, mesocarnivore*, large herbivore*, herbivore suppression, grazing, browsing, predation pressure*, interspecific, interspecific interaction*, interspecific killing, predation, intraguild predation, competition, competitor*, trophic cascade*, predation risk*, ecosystem service*). Reference trails, recommended papers or appropriate material already in the possession of the authors were also used to inform this review.

\subsection{Predation risk}

Predators consume prey but they also provide risk (Brown and Kotler 2007; Fortin et al. 2005). Harassment and the associated energetic losses of responding to predation risk can carry costs to overall fitness (Creel 2011). Predation risk is a powerful motivator that can affect behaviour and how an animal uses time and space as well as investment in other antipredator strategies (Brown et al. 1999; Ripple and Beschta 2004; Willems and Hill 2009). Predation risk and disturbance create trade-offs between avoiding risk or perceived risk and other fitness enhancing activities (e.g. feeding and breeding), such that risk avoidance carries energetic costs in the form of missed opportunities (Brown 1992; Brown et al. 1999; Eccard and Liesenjohann 2014). Human disturbance may incur similar responses to risk in wildlife (Erb et al. 2012; Frid and Dill 2002; Leighton et al. 2010).

Risk-induced interactions between predators and other organisms can have cascading effects (Miller et al. 2012; Ripple et al. 2014; Ritchie and Johnson 2009). A forager's response to its landscape of fear (Laundré et al. 2014; Laundré et al. 2010) may alter the species composition, behaviour, adaptive evolution or population dynamics of its prey and perhaps its predators or competitors (Brown and Kotler 2007). Non-consumptive behavioural interactions can be significant ecological drivers and should not be overlooked (Heithaus et al. 2009; Peckarsky et al. 2008; Ritchie and Johnson 2009).

\section{Interactions with mesopredators}


Larger predators can sometimes limit the impacts, range and densities of smaller predators (Henke and Bryant 1999; Levi and Wilmers 2012; Prugh et al. 2009). Soulé et al., (1988) observed that, in the absence of larger more dominant predators, smaller predators and omnivore populations explode: increasing abundance by up to ten times that before release. The mesopredator release hypothesis predicts that a decrease in abundance of top-order predators results in an increase in the abundance of mesopredators due to a reduction in intraguild predation and competitive suppression (Letnic and Dworjanyn 2011; Ritchie and Johnson 2009). Suppression of mesopredators can result in density reductions or even complete exclusion of these smaller predators from habitats or regions in both time and space (Berger and Gese 2007; Linnell and Strand 2000; Newsome and Ripple 2014).

Interspecific competitive killing, intraguild predation and interspecific interference competition are common in a whole range of mammalian carnivores (Lourenco et al. 2014), particularly between species with elements of niche overlap and species of the same family having not too dissimilar body mass (Linnell and Strand 2000; Palomares and Caro 1999; Ritchie and Johnson 2009). Two main mechanisms offer explanation for mesopredator suppression by apex predators, direct lethal encounters, and behavioural responses to risk (Ritchie and Johnson 2009).

There is great debate about the strength of impacts large carnivores have upon mesopredators (Allen et al. 2013; Letnic et al. 2011; Letnic et al. 2009b). There is some evidence that predation threat and impacts of mesocarnivores upon native rodents, such as Notomys fuscus, are lower in the presence of dingoes (Letnic et al. 2009a; Letnic and Dworjanyn 2011). However, some express caution in assigning causality to short-term observations of correlated, but unvalidated population indices which may falsely suggest mesopredator release (Allen et al. 2013; Fleming et al. 2012; Hayward and Marlow 2014). While there is little doubt in the value of stable ecosystems complete with top predators (Estes et al. 2011; Ripple et al. 2014), untangling the web of ecological interactions and clearly identifying ecosystem services from apex predators will require careful experimental design.

In an extensive review, Ritchie \& Johnson (2009) discuss a number of trophic assemblages where mesopredators are suppressed by larger predators and found only 2 studies identifying scenarios where scent or vocal predator cues had little impact upon mesopredators (Gehrt and Prange 2007; Prange and Gehrt 2007). Interactions between species may vary depending upon context. Larger predators may competitively suppress smaller predators but also provide scavenging opportunities (Khalil et al. 2014). Habitat complexity, resource availability and the density or complexity of predator communities may affect the outcomes of interactions between predators (Khalil et al. 2014; Ritchie and Johnson 2009). Mesopredator prey species comprise a vast array of herbivores, detritivores, seed dispersers and seed predators (Catling 1988; Panzacchi et al. 2008; Russell and Storch 2004). Such species have variable interactions with vegetation communities (Wang and Yang 2015; Yi and Wang 2015; Zamora and Matias 2014). Any consequential cascades resulting from mesopredator release are also likely to be context-dependent.

\subsection{Contexts affecting mesopredator interactions}




\subsubsection{Species assemblage}

Vulnerability and interactions between predators may be influenced by niche overlap and relatedness (Berger and Gese 2007; Gehrt and Prange 2007; Ritchie and Johnson 2009), but also by species specific factors such as defence or grouping behaviour (Cooper 1991; Palomares and Caro 1999; Prange and Gehrt 2007). Mesopredators, such as the bobcat Carnivora Felidae Lynx rufus (5-15kg), can coexist with larger predators of similar size but different families, like the coyote Carnivora Canidae Canis latrans (8-20kg), even when a smaller mesopredator the grey fox Carnivora Canidae Urocyon cinereoargenteus (3-5kg) did not (Fedriani et al. 2000).

In many North American trophic systems lacking larger carnivores, coyotes can interact competitively and suppress mesocarnivores (Henke and Bryant 1999; Kamler et al. 2003; Linnell and Strand 2000). The extent of this suppression may be somewhat dependent on the presence of other predators. Red fox Carnivora Canidae Vulpes vulpes for example pose more of a threat to kit fox Carnivora Canidae Vulpes macrotis populations because they can access dens (Cypher et al. 2001; Ralls and White 1995). Coyotes could have an additive negative impact (through predation) or benefit kit foxes through interference competition and suppression of red foxes (Cypher et al. 2001).

In the presence of a larger canid, coyotes were supressed by wolves and red foxes became more abundant (Levi and Wilmers 2012). North American wolves impact coyote distribution, abundance (33\% lower in wolf abundant sites) and dispersal survival rates (Berger and Gese 2007; Newsome and Ripple 2014). In the presence of a feline apex predator however, coyotes were only killed by mountain lions Carnivora Felidae Puma concolor defending or usurping food caches during winter when diets overlapped significantly more (Koehler and Hornocker 1991). The overall impacts of predator communities and the outcomes of mesopredator suppression might depend directly on the number, density and composition of predator dominance levels (Chakarov and Krueger 2010).

At its most extreme scale, human influence can result in mesopredator range expansion and population growth, through the removal of apex predators (Kamler et al. 2003; Ripple et al. 2013; Selås and Vik 2006) or competing mesopredators (Courchamp et al. 1999; Rayner et al. 2007; Trewby et al. 2008). In some circumstances, release can result in the increase of a prey source shared by apex and mesopredators (Henke and Bryant 1999). Decline in prey species of mesopredators is however more common (Elmhagen et al. 2010; Sargeant et al. 1984; Sovada et al. 1995). Caution must be expressed when interfering with ecological interactions as mesopredator release can carry economic and social costs (Prugh et al. 2009).

The introduction of alien predators may also alter trophic dynamics, complicating intraguild competition and affecting food webs (Crooks and Soulé 1999; Krauze-Gryz et al. 2012; Rayner et al. 2007). Wolf-dog interactions in particular stand out as an anthropogenic introduction to species assemblage with variable context-dependent outcomes (Lescureux and Linnell 2014). Levels of co-existence between native and alien species may be dependent on niche flexibility, landscape and resource abundance (Bonesi et al. 2004; Bonesi and 
Macdonald 2004; Brzezinski et al. 2008). The maintenance and recovery of native or naturalised predators may in some contexts help to mitigate the impacts of invasive mesopredators (Glen et al. 2007; McDonald et al. 2007; Ritchie et al. 2012). Introduced predators, although posing their own threat to native prey species may also suppress the impacts of smaller alien predators in certain contexts (Hanna and Cardillo 2014). Predator eradication can have unforeseen consequences even with conservation in mind. Invasive species removal may have undesired effects through mesopredator release, rather than alleviating predation pressure upon native species as intended (Rayner et al. 2007).

\subsubsection{Environmental productivity}

Apex predators can affect food availability to smaller predators through the provision of carrion (Wilmers and Getz 2005), exploitative competition (Selås and Vik 2006), kleptoparasitism (Gorman et al. 1998), landscapes of fear (Kuijper et al. 2013; Laundré et al. 2010), and possibly through indirect impacts on habitat structure and provisioning of refuge for mesopredator prey (Letnic and Dworjanyn 2011). Bottom-up factors however influence population densities of herbivores and consequently their predators (East 1984; Hayward et al. 2007).

The strength of top-down mesopredator control and consequently the strength of cascades from large carnivores can be determined by ecosystem productivity (Elmhagen et al. 2010; Elmhagen and Rushton 2007; Hollings et al. 2014). In contexts where bottom up effects are strongly influential the mesopredator release response to apex predator control may be limited. Coyote predation upon kit foxes can account for 75-90\% of mortality (Eliason and Berry 1994; Linnell and Strand 2000; Ralls and White 1995). Such predation may be most significant when food availability is low or when kit fox populations are small (Cypher et al. 2001). During a coyote control programme where kit fox release did not occur as expected, food availability (lagomorph abundance) was observed to be the primary factor driving population dynamics of both species (Cypher and Scrivner 1992).

Humans can influence the type and severity of interspecific competition amongst carnivores by artificially boosting food availability, and consequently mesopredator populations (Bateman and Fleming 2012; Crooks and Soulé 1999; Linnell and Strand 2000). Maintaining mesopredators far above their carrying capacity with nutritional subsidies may particularly unbalance natural regulation if accompanied by habitat fragmentation (Crooks and Soulé 1999; Dickman 2008). Large carnivores can also adapt to capitalize on anthropogenic food sources (Ciucci et al. 1997; Kusak et al. 2005; Newsome et al. 2014). However, humans often inhibit large carnivore use of space and time (Whittington et al. 2005). Both direct and indirect human influence on prey numbers, accessibility and hunting opportunities may cause prey switching and impact activity patterns with consequences for competitive interactions and the resultant impacts of large carnivores (Allen and Leung 2012; Theuerkauf et al. 2003).

\subsubsection{Landscape}

The interplay between predation risk and habitat features can shape foraging decisions and habitat use (Camacho 2014). Predation risk is not homogenous across landscapes or species; 
habitat features can interact with escape tactics to shape interspecific interactions (Wirsing et al. 2010). Predation risk is not always driven by predator density alone and mesopredator landscape use can sometimes be more dominantly driven by habitat features (Heithaus et al. 2009).

In many cases humans have drastically reduced available habitat for native fauna (Paquet and Darimont 2010). The impacts large carnivores have on other species and ecosystems may be relative to their interactions with anthropogenic landscapes. Human landscape modification may alter species interactions and occupancy by benefitting those species more adaptable to anthropogenic disturbance (Cove et al. 2012; Erb et al. 2012; Ruiz-Capillas et al. 2013). Urban predators can provide ecosystem services as well as conflicts but human conflict often dominates management decisions (Dodge and Kashian 2013).

Human presence does not always necessitate extreme avoidance by large carnivores (Theuerkauf et al. 2007) and not all human landscapes will inhibit ecological interactions between predators (Berry et al. 1992; Standley et al. 1992). Landscape modification and the management of larger predators in fenced reserves for example can also have conservation benefits for mesopredators (Van Dyk and Slotow 2003). In other contexts, human landscape use may have negligible impact on mesopredator occupancy (Schuette et al. 2013) or negative effects through elevated populations of domestic competitors (Krauze-Gryz et al. 2012).

\subsubsection{Predation risk}

As well as direct killing, large carnivores impact habitat use and foraging effort of smaller mesopredators (Palomares and Caro 1999; Ritchie and Johnson 2009; Thurber et al. 1992). Interference competition between carnivores through harassment (Berger and Gese 2007; Linnell and Strand 2000; Mukherjee et al. 2009), prey competition (Cypher et al. 2001) and kleptoparasitism (Cooper 1991; Gorman et al. 1998) can generate avoidance of larger carnivores through spatio-temporal partitioning (Crooks and Soulé 1999; Durant 2000; Hayward and Slotow 2009).

Rarity and inconsistency of agonistic interactions and/or behavioural avoidance of encounters may permit co-existence between some predators (Durant 2000; Fedriani et al. 2000). Distribution of predators over large spatial scales can however be driven by competitive interactions (Elmhagen et al. 2010; Newsome and Ripple 2014). Mesopredators sometimes use peripheries of larger predator territories (Berger and Gese 2007; Miller et al. 2012; Thurber et al. 1992), presumably reducing encounter rates and increasing fitness. Fearful interactions between predators may permit the co-existence of multiple prey species, with certain species existing where dominant predators limit the spatio-temporal presence of subordinate predators (Berger et al. 2008; Miller et al. 2012).

As a consequence of interspecific aggression between carnivores (Berger and Gese 2007; Palomares and Caro 1999; Thurber et al. 1992), foraging decisions by mesopredators are also influenced by risk from their own predators (Mukherjee et al. 2009; Ritchie and Johnson 2009; Roemer et al. 2009). The extent to which mesopredators are impacted by larger 
predators and the degree to which they have to adjust their foraging efforts, activity patterns, vigilance and risk taking is likely to vary depending on predator assemblage, habitat and food availability (Ritchie and Johnson 2009).

Humans can also influence interspecific interactions (Crooks and Soulé 1999). Additional anthropogenic landscapes of fear (Frid and Dill 2002) could further limit foraging opportunities for mesopredators. Alternatively anthropogenic interference with larger predators (Erb et al. 2012; George and Crooks 2006; Theuerkauf et al. 2003) could potentially reduce suppression.

\section{Interactions with large herbivores}

Large carnivores can be important mortality drivers of ungulate populations (Jędrzejewski et al. 2002; Melis et al. 2009), maintaining herd health through the removal of unhealthy individuals (Kusak et al. 2012). Although not universal, density-driven terrestrial cascades are common (Schmitz et al. 2000). On Isle Royale, USA for example, wolves have been found to regulate moose Cetartiodactyla Cervidae Alces alces population dynamics and in doing so dampen the effects of climactic change upon herbivore and scavenger communities (Wilmers et al. 2006).

Both herbivore density and behaviour can be altered by the presence and actions of predators (Beckerman et al. 1997; Montgomery et al. 2013). In many circumstances the role of "landscapes of fear" (Laundré et al. 2010), predation risk and the avoidance of predators are also believed to be closely linked to how ungulates use time and space (Brown et al. 1999; Harmsen et al. 2011; Kronfeld-Schor and Dayan 2003) as well as how they forage (Altendorf et al. 2001; Kotler et al. 1994; Laundré et al. 2001). There is an increasing amount of literature investigating the impacts that ungulate foraging patterns may have upon ecosystems and vegetation community structure (Gill 2000; Reimoser et al. 1999; Tschöpe et al. 2011). Large carnivores may hold influence over patterns of ungulate grazing pressure and its consequent impacts (Creel et al. 2005; Estes et al. 2011; Ripple and Beschta 2004).

There is a great deal of flexibility in how large carnivores such as wolves use time and space (Kusak and Haswell 2013). The causal factors behind activity patterns are highly variable (Ballard et al. 1997; Kolenosky and Johnston 1967; Theuerkauf 2009). Anthropogenic influences are often strong drivers (Ciucci et al. 1997; Kusak et al. 2005; Theuerkauf et al. 2003). How large carnivores interact with herbivores is likely to be dependent on this context. Foraging and space-time use patterns of herbivores and the role of behaviourally-mediated carnivore impacts may ultimately dictate potential ecosystem services that could benefit local communities (Hebblewhite et al. 2005; Ripple et al. 2014). However trophic cascades from large carnivores are not guaranteed in every ecological context (Ford et al. 2015).

\subsection{Context's affecting interactions with large herbivores}

\subsubsection{Species assemblage}

In Europe, the limiting effects of lynx Carnivora Felidae Lynx lynx and wolf upon roe deer Cetartiodactyla Cervidae Capreolus capreolus density were stronger when both species were 
present than by one species alone (Melis et al. 2009). Where one species was present alone (most commonly the wolf) mean roe deer density was 917 per $100 \mathrm{~km}^{2}$ but only 167 in the presence of both predators (Melis et al. 2009). This suggests that predators can have additive effects on shared prey and that generally lynx are a more dominant predator of roe deer in Europe. The composition of large carnivores in a given scenario is clearly consequential to the effects upon herbivore communities.

In south-eastern Norway, roe deer fawns were consumed by red foxes ( $8.6 \%$ spring-summer diet, (Panzacchi et al. 2008). Red foxes had a highly varied diet so fawns were not considered important to the population dynamics of red foxes, implying that there was unlikely to be any stabilising feedback mechanism between the species (Panzacchi et al. 2008). Where mesopredators are released from apex predator suppression, mesopredators could have more pronounced impacts on herbivore recruitment (Berger et al. 2008). This may offer some compensation for a lack of adult ungulate predation by large carnivores. However, even if density-driven effects could be compensated by mesopredators, smaller carnivores are unlikely to replace the behavioural dynamics between larger carnivores and adult ungulates.

Harvesting of larger trophy individuals or the removal of larger predators in general due to human conflicts could have catastrophic effects (Packer et al. 2009). Larger wolves $>39 \mathrm{~kg}$ (usually older and/or male animals) have been observed to have higher attack and kill rates in Yellowstone National Park where improvements in handling success are not counteracted by a reduction in pursuit ability (MacNulty et al. 2009). The association between increased body weight and prey size in carnivores could be driven by size-related energetic costs (Carbone et al. 1999; Carbone et al. 2007) and size-related predator performance (MacNulty et al. 2009). Local conditions may affect composition and characteristics (gender, size or age) of predator social groups (Van Orsdol et al. 1985). Food loss rates from kleptoparasites like ravens are relative to wolf pack size and can consequently further affect kill rates (Hayes et al. 2000; Kaczensky et al. 2005). Temporal success, preferences and social structure can influence predation rates and consumption of different prey species (Jędrzejewski et al. 2002). Social dynamics and population demography could also influence the direction or strength of cascades due to predation patterns.

Interspecific relationships may also have a variable temporal context that is not constant (Koehler and Hornocker 1991). Herbivores can have seasonal habitat preferences and dietary requirements (Degmečić et al. 2011). Large carnivores can also exhibit seasonal or context driven dietary shifts (Garrott et al. 2007; Latham et al. 2013; Odden et al. 2006) and habitat use (Alexander et al. 2006). Population structure, body condition, parasite load, climate, predator density and predation risk may all interact to drive herbivore landscape use (Montgomery et al. 2013).

Herbivore response to risk may in itself be subject to competitive partitioning between herbivores, particularly around key habitat sites such as water sources (Hayward and Hayward 2012). Resource competition between herbivores may alter landscape use patterns (Dolman and Waber 2008; Hibert et al. 2010). While displacement is context specific and 
likely to be dependent on levels of niche overlap (Iranzo et al. 2013), the potential for domestic herbivores to outcompete wild herbivores is probably high (Latham 1999).

Wild and domestic herbivores forage and interact with vegetation communities in different ways, with domestic stock often causing greater degradation (Fuller 2001; Hester and Baillie 1998; Hill et al. 1991). Domestic livestock often aggregate more, and their limited ranging behaviour is exacerbated through herding and human directed foraging at convenient locations (Albon et al. 2007). This type of herbivory will likely result in limited impacts from large carnivores upon domestic grazing/browsing pressure, with consequences being predominantly human driven. When livestock are free-ranging their response to predation risk is still different to that of wild herbivores, as well as being somewhat attenuated (Muhly et al. 2010).

The introduction of competitive alien herbivores (e.g. domestic stock) can also lead to apparent competition and increased predation of native species by predators (Dolman and Waber 2008). Poor husbandry practices and high livestock predation rates could potentially either exacerbate or reduce large carnivore impacts on native species depending on context. Furthermore, livestock guarding dogs that accompany livestock interact with predators (Lescureux and Linnell 2014). Livestock guarding dogs, along with human presence may add to landscapes of fear for large carnivores but may also serve to maintain interactions between predators and native prey.

The traditional role of humans as part of the predator guild in communities is often overlooked. Aboriginal hunters were important apex predators in Australia following their arrival and the extinction of the megafauna (Fleming et al. 2012). In the absence of its human hunting partners, the dingo may not truly fulfil the role of an apex predator and its modern ecological function may differ given vast anthropogenic habitat modification (Fleming et al. 2012). In a similar fashion, our understanding of how indigenous North American's impacted the landscape is still developing (Lightfoot et al. 2013). The sustainability of such impacts are debateable, but it is clear that the removal of human regimes from wilderness designations in the USA will not replicate the ecological conditions present since its colonisation by European settlers (Kay 1994).

The role of humans in the modern food web and the very different nature of our interactions and impacts is something worth considering. Modern hunting practices and regulations vary dramatically across the globe and the impacts will no doubt vary too. The attractive rewilding concept of re-establishing self-sustaining ecosystems with minimal human disruption may help to maintain large carnivore-herbivore interactions, but requires careful consideration of desired outcomes (Brown et al. 2011). Such management intervention may not always be pragmatic or necessarily a true reflection of the historic status quo. An understanding of how humans influence trophic dynamics could help to better predict and steer landscape management to desired outcomes.

\subsubsection{Ecosystem productivity}


Resource driven landscape use (Owen-Smith 2014) and bottom-up effects of environmental productivity are often a major driving force influencing large herbivore distribution and abundance (Coe et al. 1976; East 1984; Karanth et al. 2004). For example, roe deer abundance in Europe was positively correlated with environmental productivity (Melis et al. 2009). The impacts of large predators were however weak in productive environments and regions with mild climate but noticeably greater in regions with harsher winters and lower productivity (Melis et al. 2009). Climatic features such as temperature or snow depth can also interact with local complexities, impacting the strength of predation pressure and trophic cascades (Post et al. 1999; Sanford 1999). The strength of impacts from large carnivores may be dependent on productivity and climatic context.

A forager in a low energy state has less to lose from predation and a higher marginal value of energy to be gained so is more likely to forage in riskier habitats, change their forage selection decisions and reduce food patches to a greater extent (Brown and Kotler 2007; Brown et al. 1992; Hayward et al. 2015). Competition for game animals between humans and large carnivores (Virgos and Travaini 2005) may affect predator energy states and consequently predation patterns. Conversely, anthropogenic food provisioning, such as at refuse (Ciucci et al. 1997), urban (Rodewald et al. 2011) or hunting sites (Selva et al. 2014) may alter predation risk trade-offs and interactions between species, potentially decoupling interspecific relationships (Rodewald et al. 2011). Where anthropogenic foods dominate predator diet, impacts of large carnivores upon wild herbivores could become minimal or alternatively could increase due to inflated predator numbers, energy or time resources.

\subsubsection{Landscape}

Landscape-scale or micro-habitat predation patterns of large carnivores can impact upon local vegetation communities. Wolf predation of deer can impact habitat heterogeneity through the creation of nutrient pulses at kill sites (Bump et al. 2009). Wolf predation success and prey vulnerability may be dependent on the amount of open grassland adjacent to streams (Kauffman et al. 2007). If large herbivores are predated more successfully and forage less in high risk areas (Crosmary et al. 2012; Fortin et al. 2005; Ripple and Beschta 2004), one might expect woody plant regeneration and vegetation succession (Berger 1999; Berger et al. 2001a; Hebblewhite et al. 2005).

In Yellowstone National Park's northern winter range, elk Cetartiodactyla Cervidae Cervus canadensis movement preference for vegetative cover types was influenced by the spatial distribution of wolves (Fortin et al. 2005). Risk driven habitat preferences may be responsible for observed reductions in aspen Malpighiales Salicaceae Populus tremuloides browsing pressure by elk in the presence of wolves (Fortin et al. 2005; Ripple and Larsen 2000; Ripple et al. 2001). The extent of the impacts behaviourally-mediated trophic cascades have on aspen recruitment in Yellowstone has however been debated (Beschta et al. 2014; Kauffman et al. 2010; Winnie 2014; Winnie 2012). Trophic cascades may be more complicated than the three tiered systems proposed; in complicated food webs interactions can go up, across and down the trophic web (Polis et al. 2000; Strong 1992). In Yellowstone, interactions between environmental productivity, habitat features, human activities outside the park, predators and 
herbivores, as well as contributing impacts of engineers, such as beavers Rodentia Castoridae Castor canadensis, are likely to contribute and interact to affect vegetation communities through both behaviourally- and density-mediated mechanisms (Marshall et al. 2013; Painter et al. 2015).

Anthropogenic landscape alterations such as higher road densities, fire regimes and housing developments can have negative impacts on the presence and activity of large carnivores (Haskell et al. 2013; Hebblewhite et al. 2009; Theuerkauf et al. 2003). Anthropogenic disturbance may span further than expected, with activities outside protected areas having strong effects on species within reserves (Parks and Harcourt 2002). Even human landscape modification intended to conserve (e.g. fenced reserves) may alter natural predator-prey dynamics through consequent changes in prey vulnerability and predator behaviour (DaviesMostert et al. 2013). Human landscape alteration can also create new landscapes of fear for large herbivores (Semeniuk et al. 2014). Such interferences could inhibit desirable ecological interactions.

\subsubsection{Predation risk}

Through behavioural mechanisms predators can influence prey species landscape use (Laundré et al. 2001; Laundré et al. 2014; Willems and Hill 2009) and consequently the impacts of herbivores upon habitat structure (Fortin et al. 2005; Kuijper et al. 2013). How populations and individuals respond to predation risk is unlikely to be consistent across contexts. Behavioural responses to environmental cues of predation risk may be sensitive to fluctuations in predation pressure (Berger 1999) but can also remain stable in its absence (Chamaille-Jammes et al. 2014). The strength of response to risk and the relative influence of predation risk to a predator's overall limiting effect is likely to be affected by the environment as well as predator and prey characteristics (Creel 2011). It is suggested that prey species respond to overall risk rather than predator abundance alone (Heithaus et al. 2009). In some circumstances, prey species escape probability, habitat use and consequently resource exploitation can be higher where predators are more abundant (Heithaus et al. 2009). Individual factors such as gender (Laundré et al. 2001) and the presence of offspring (Wolff and Horn 2003) can also influence investment in anti-predatory responses like vigilance.

470 Risk of predation can cause prey to be more cautious in how they forage, becoming more vigilant (Altendorf et al. 2001; Halofsky and Ripple 2008; Wolff and Horn 2003), more mobile, thereby reducing predictability (Fortin et al. 2009), alter habitat use (Creel et al. 2005; Fortin et al. 2005; Laundré et al. 2001), respond to risk cues (Berger 1999; Mella et al. 2014), forage less in risky patches (Andruskiw et al. 2008; Brown 1988; Koivisto and Pusenius 2006) or at restricted times (Brown and Kotler 2007), forage in larger groups diluting risk (Fortin et al. 2009; Hebblewhite et al. 2002; Isvaran 2007) or in smaller groups reducing detection (Fortin et al. 2009; Hebblewhite et al. 2002). In any one circumstance a myriad and combination of these antipredator tactics may be implemented. 
and predation risk create somewhat of a tactical predator-prey foraging game. "Prey face different risks from predators with different tactics, and their antipredator responses vary accordingly" (Creel 2011). Predator specific strategies in prey may also promote coexistence among predator species, if employing vigilance or avoidance strategies against one sort of predator causes the forager to be more vulnerable to another (Sih et al. 1998).

Variation in response to predators may be driven by local selective pressures. Predator hunting strategies, foraging behaviour and social organisation of herbivores alongside environmental variables will lead to context-dependent herbivore response to predation risk (Samelius et al. 2013). Prey species response to predation risk in turn impacts lower trophic levels in what is ambiguously known as a trophic cascade (Polis et al. 2000).

Human activities can also impact patch predation risk, landscapes of fear and habitat use by both predators and large herbivores (Hebblewhite et al. 2009; Rogala et al. 2011; Sibbald et al. 2011). Non-consumptive (Blanc et al. 2006; Frid and Dill 2002; Leighton et al. 2010) and consumptive (Ciuti et al. 2012; Proffitt et al. 2013; Sand et al. 2006) human interactions with large herbivores can affect predation risk responses. Whether an elk was harvested by humans or not in North America was found to be a consequence of individual response to a human mediated landscape of fear (Ciuti et al. 2012). Older female elk generally adopted habitat preferences and the use of a running or hiding strategy that lead to their survival (Ciuti et al. 2012).

In the absence of human hunting pressures large herbivores may adjust their behaviour in response to large carnivores (Berger et al. 2001b). Human interactions with ungulates may sometimes benefit large carnivores (Kilgo et al. 1998). However, anthropogenic selection can also impact behavioural evolution and herbivore learning in a different and opposing manner to that of large carnivores, potentially negating their impacts (Ciuti et al. 2012; Sand et al. 2006).

Individual behaviour, learning and the selective pressures of large carnivores and humans over time may be important drivers of large herbivore behaviour and its potential cascading effects. It is essential to know whether human interactions yield desired outcomes or interfere with the impacts of large carnivores through intensified or competing selection pressures.

\section{Conclusions}

Interactions between species are complicated. Suppression of one species by another can be driven by a varying intensity of both density- and behaviourally-mediated mechanisms. Impacts from large carnivores will not be homogenous across contexts. Factors intrinsic to prey, predators and the given system (species composition, environmental productivity, landscape, and predation risk) will culminate to produce the resultant dynamics in a given context. The mixture of variables yielding interspecific relationships with large carnivores in a given context will in turn interact with additional features at lower trophic levels, dictating further interspecific interactions, ecosystem services and the presence of trophic cascades from large carnivores. 
Human-induced changes could have cascading effects for the entire carnivore community, on prey communities of both apex and mesopredators and consequently habitat structure and biodiversity (Fig.1). The impacts of humans on other species, the types and intensity of human activity in a given context could alter the direction or severity of other interspecific interactions (Table 1). Humans can remove large carnivores from systems altogether, undesirably influence large carnivore activity, disrupt foraging, reduce survival success or breeding capability, suppress habitat use and ultimately interfere with trophic interactions.

An understanding of whole ecosystems and the processes that maintain them is key to ensuring sustainability. If we are to understand ecological systems, it is important for basic monitoring of common as well as rare species to be undertaken alongside novel experimental approaches. Whilst managers, politicians and the public might desire standardised answers, blanket assumptions of the role of large carnivores across contexts and inflexible or misinformed approaches to their management are damaging. In order to take appropriate management and conservation action in any given context, interspecific interactions, the outcome of human interference and the trade-off between ecosystem services and anthropogenic land uses must be informed by robust experimentation and analysis. It is imperative that the consequences of intervention, particularly predator control are understood.

\section{Acknowledgements}

We would like to thank Bangor University and the University of Zagreb for their support of the authors. Both Haswell and Kusak would also like to thank The UK Wolf Conservation Trust, Nacionalni park Sjeverni Velebit and Nacionalni park Plitvička jezera for their continued assistance and support of research efforts with the study of large carnivores in Croatia. We are grateful to Dr. B. Allen and Dr. S. Creel for their useful comments on the manuscript. The authors declare that they have no conflict of interest in the authorship of this article.

\section{$\underline{\text { References }}$}

1. Albon, S.D., Brewer, M.J., O’Brien, S., Nolan, A.J., Cope, D., 2007. Quantifying the grazing impacts associated with different herbivores on rangelands. J. Appl. Ecol. 44, 1176-1187.

2. Alexander, S.M., Logan, T.B., Paquet, P.C., 2006. Spatio-temporal co-occurrence of cougars (Felis concolor), wolves (Canis lupus) and their prey during winter: a comparison of two analytical methods. J. Biogeogr. 33, 2001-2012.

3. Allen, B.L., Fleming, P.J.S., Allen, L.R., Engeman, R.M., Ballard, G., Leung, L.K.P., 2013. As clear as mud: A critical review of evidence for the ecological roles of Australian dingoes. Biol. Conserv. 159, 158-174.

4. Allen, B.L., Leung, L.K.P., 2012. Assessing predation risk to threatened fauna from their prevalence in predator scats: dingoes and rodents in arid Australia. PLOS. ONE. 7, e36426.

5. Altendorf, K.B., Laundré, J.W., López González, C.A., Brown, J.S., 2001. Assessing effects of predation risk on foraging behavior of mule deer. J. Mammal. 82, 430-439.

6. Andruskiw, M., Fryxell, J.M., Thompson, I.D., Baker, J.A., 2008. Habitat-mediated variation in predation risk by the American marten. Ecology. 89, 2273-2280. 
7. Ballard, W., Ayres, L., Krausman, P., Reed, D., Fancy, S., 1997. Ecology of wolves in relation to a migratory caribou herd in northwest Alaska. Wildlife. Monogr. 135, 3-47.

8. Bateman, P.W., Fleming, P.A., 2012. Big city life: carnivores in urban environments. J. Zool. 287, 1-23.

9. Beckerman, A.P., Uriarte, M., Schmitz, O.J., 1997. Experimental evidence for a behaviormediated trophic cascade in a terrestrial food chain. Proc. Nat.I Acad. Sci. USA. 94, 1073510738.

10. Berger, J., 1999. Anthropogenic extinction of top carnivores and interspecific animal behaviour: Implications of the rapid decoupling of a web involving Wolves, Bears, Moose and Ravens. Proc. R. Soc. B. 266, 2261-2267.

11. Berger, J., 2008. Undetected species losses, food webs, and ecological baselines: a cautionary tale from the Greater Yellowstone Ecosystem, USA. Oryx. 42, 139-142.

12. Berger, J., Stacey, P., Bellis, L., Johnson, M., 2001a. A Mammalian Predator-Prey Imbalance: Grizzly Bear and Wolf Extinction Affect Avian Neotropical Migrants. Ecol. Appl. 11, 947-960.

13. Berger, J., Swenson, J.E., Persson, I.L., 2001b. Recolonizing carnivores and naive prey: Conservation lessons from Pleistocene extinctions. Science. 291, 1036-1039.

14. Berger, K., Gese, E., 2007. Does interference competition with wolves limit the distribution and abundance of coyotes? J. Anim. Ecol. 76, 1075-1085.

15. Berger, K.M., Gese, E.M., Berger, J., 2008. Indirect effects and traditional trophic cascades: A test involving wolves, coyotes, and pronghorn. Ecology. 89, 818-828.

16. Berry, W.H., Standley, W.G., O'Farrell, T.P., Kato, T.T., 1992. Effects of military-authorized activities on the San Joaquin kit fox (Vulpes velox macrotis) at Camp Roberts Army National Guard Training Site, California. EG and G Energy Measurements, Inc., Goleta, CA (United States). Santa Barbara Operations.

17. Beschta, R.L., Eisenberg, C., Laundre, J.W., Ripple, W.J., Rooney, T.P., 2014. Predation risk, elk, and aspen: comment. Ecology. 95, 2669-2671.

18. Beschta, R.L., Ripple, W.J., 2012. The role of large predators in maintaining riparian plant communities and river morphology. Geomorphology. 157, 88-98.

19. Blanc, R., Guillemain, M., Mouronval, J.-B., Desmonts, D., Fritz, H., 2006. Effects of nonconsumptive leisure disturbance to wildlife. Rev. Ecol-Terre. Vie. 61, 117-133.

20. Bonesi, L., Chanin, P., Macdonald, D.W., 2004. Competition between Eurasian otter Lutra lutra and American mink Mustela vison probed by niche shift. Oikos. 106, 19-26.

21. Bonesi, L., Macdonald, D.W., 2004. Differential habitat use promotes sustainable coexistence between the specialist otter and the generalist mink. Oikos. 106, 509-519.

22. Brown, C., McMorran, R., Price, M.F., 2011. Rewilding - A New Paradigm for Nature Conservation in Scotland? Scott. Geogr. J. 127, 288-314.

23. Brown, J.S., 1988. Patch use as an indicator of habitat preference, predation risk, and competition. Behav. Ecol. Sociobiol. 22, 37-47.

24. Brown, J.S., 1992. Patch use under predation risk: I. Models and predictions. Ann. Zool. Fenn. 29, 301-309.

25. Brown, J.S., Kotler, B.P., 2007. Foraging and the ecology of fear, In Foraging Behaviour and Ecology. eds D.W. Stephens, J.S. Brown, R.C. Ydenberg, pp. 438-480. University of Chicago Press, Chicago USA.

26. Brown, J.S., Laundré, J.W., Gurung, M., 1999. The ecology of fear: optimal foraging, game theory, and trophic interactions. J. Mammal. 80, 385-399. 
27. Brown, J.S., Morgan, R.A., Dow, B.D., 1992. Patch use under predation risk: II. A test with fox squirrels, Sciurus niger. Ann. Zool. Fennici. 29, 311-318.

28. Brzezinski, M., Swiecicka-Mazan, A., Romanowski, J., 2008. Do otters and mink compete for access to foraging sites? A winter case study in the Mazurian Lakeland, Poland. Ann. Zool. Fennici. 45, 317-322.

29. Bump, J.K., Peterson, R.O., Vucetich, J.A., 2009. Wolves modulate soil nutrient heterogeneity and foliar nitrogen by configuring the distribution of ungulate carcasses. Ecology. 90, 31593167.

30. Camacho, C., 2014. 'Bodyguard' plants: Predator-escape performance influences microhabitat choice by nightjars. Behav. Process. 103, 145-149.

31. Carbone, C., Mace, G.M., Roberts, S.C., Macdonald, D.W., 1999. Energetic constraints on the diet of terrestrial carnivores. Nature. 402, 286-288.

32. Carbone, C., Teacher, A., Rowcliffe, J.M., 2007. The costs of carnivory. PLOS. Biol. 5, 363-368.

33. Catling, P.C., 1988. Similarities and contrasts in the diets of foxes, Vulpes vulpes, and cats, Felis catus, relative to fluctuating prey populations and drought. Aust. Wildl. Res. 15, 307317.

34. Chakarov, N., Krueger, O., 2010. Mesopredator Release by an Emergent Superpredator: A Natural Experiment of Predation in a Three Level Guild. PLOS. ONE. 5.

35. Chamaille-Jammes, S., Malcuit, H., Le Saout, S., Martin, J.L., 2014. Innate threat-sensitive foraging: black-tailed deer remain more fearful of wolf than of the less dangerous black bear even after 100 years of wolf absence. Oecologia. 174, 1151-1158.

36. Chamberlain, S.A., Bronstein, J.L., Rudgers, J.A., 2014. How context dependent are species interactions? Ecol. lett. 17, 881-890.

37. Chapron, G., Kaczensky, P., Linnell, J. D., Von Arx, M., Huber, D., Andrén, H., López-Bao, J. B., Adamec, M., Álvares, F., Anders, O., Balčiauskas, L., Balys, V., Bedő, P., Bego, F., Blanco, J. C., Breitenmoser, U., Brøseth, H., Bufka, L., Bunikyte, R., Ciucci, P., Dutsov, A., Engleder, T., Fuxjäger, C., Groff, C., Holmala, K., Hoxha, B., Iliopoulos, Y., Ionescu, O., Jeremić, J., Jerina, K., Kluth, G., Knauer, F., Kojola, I., Kos, I., Krofel, M., Kubala, J., Kunovac, S., Kusak, J., Kutal, M., Liberg, O., Majić, A., Männil, P., Manz, R., Marboutin, E., Marucco, F., Melovski, D., Mersini, K., Mertzanis, Y., Mysłajek, R. W., Nowak, S., Odden, J., Ozolins, J., Palomero, G., Paunović, M., Persson, J., Potočnik, H., Quenette, P-Y., Rauer, G., Reinhardt, I., Rigg, R., Ryser, A., Salvatori, V., Skrbinšek, T., Stojanov, A., Swenson, J. E., Szemethy, L., Trajçe, A., TsingarskaSedefcheva, E., Váňa, M., Veeroja, R., Wabakken, P., Wölfl, M., Wölfl, S., Zimmermann, F., Zlatanova, D., Boitani, L., 2014. Recovery of large carnivores in Europe's modern humandominated landscapes. Science. 346 1517-1519.

38. Ciucci, P., Boitani, L., Francisci, F., Andreoli, G., 1997. Home range, activity and movements of a wolf pack in central Italy. J. Zool. Lond. 243, 803-819.

39. Ciuti, S., Muhly, T.B., Paton, D.G., McDevitt, A.D., Musiani, M., Boyce, M.S., 2012. Human selection of elk behavioural traits in a landscape of fear. Proc. R. Soc. B. 279, 4407-4416.

40. Coe, M.J., Cumming, D.H., Phillipson, J., 1976. Biomass and production of large African herbivores in relation to rainfall and primary production. Oecologia. 22, 341-354.

41. Cooper, S.M., 1991. Optimal hunting group size: the need for lions to defend their kills against loss to spotted hyaenas. Afr. J. Ecol. 29, 130-136.

42. Courchamp, F., Langlais, M., Sugihara, G., 1999. Cats protecting birds: modelling the mesopredator release effect. J. Anim. Ecol. 68, 282-292. 
43. Cove, M.V., Jones, B.M., Bossert, A., Clever, D.R., Dunwoody, R.K., White, B.C., Jackson, V.L., 2012. Use of Camera Traps to Examine the Mesopredator Release Hypothesis in a Fragmented Midwestern Landscape. Am. Midl. Nat. 168, 456-465.

44. Creel, S., 2011. Toward a predictive theory of risk effects: hypotheses for prey attributes and compensatory mortality. Ecology. 92, 2190-2195.

45. Creel, S., Winnie, J.J., Maxwell, B., Hamlin, K., Creel, M., 2005. Elk alter habitat selection as an antipredator response to wolves. Ecology. 86, 3387-3397.

46. Crooks, K.R., Soulé, M.E., 1999. Mesopredator release and avifaunal extinctions in a fragmented system. Nature. 400, 563-566.

47. Crosmary, W.G., Valeix, M., Fritz, H., Madzikanda, H., Côté, S.D., 2012. African ungulates and their drinking problems: hunting and predation risks constrain access to water. Anim. Behav. 83, 145-153.

48. Cypher, B.L., Clark Jr, H.O., Kelly, P.A., Job, C.V.H., Warrick, G.D., Williams, D.F., 2001. Interspecific interactions among wild canids: implications for the conservation of endangered San Joaquin kit foxes. Endanger. Species. UPD. 18, 171-174.

49. Cypher, B.L., Scrivner, J.H., 1992. Coyote control to protect endangered San Joaquin kit foxes at the naval petroleum reserves, California, In 15th Vertebrate Pest Conference. eds J.E. Borrecco, R.E. Marsh, pp. 42-47. University of California Davis, Hyatt Newporter, Newport Beach, California.

50. Davies-Mostert, H.T., Mills, M.G.L., Macdonald, D.W., 2013. Hard boundaries influence African wild dogs' diet and prey selection. J. Appl. Ecol. 50, 1358-1366.

51. Degmečić, D., Gros, R., Florijančić, T., Ozimec, S., Bošković, I., 2011. Habitat Use and Activity of Roe Deer (Capreolus capreolus L.) in Eastern Croatia. Agric. Conspec. Sci. 76, 197-200.

52. Dickman, C.R., 2008. Indirect interactions and conservation in human-modified environments. Anim. Conserv. 11, 11-12.

53. Dobson, A., Lodge, D., Alder, J., Cumming, G.S., Keymer, J., McGlade, J., Mooney, H., Rusak, J.A., Sala, O., Wolters, V., Wall, D., Winfree, R., Xenopoulos, M.A., 2006. Habitat loss, trophic collapse, and the decline of ecosystem services. Ecology. 87, 1915-1924.

54. Dodge, W.B., Kashian, D.M., 2013. Recent Distribution of Coyotes Across an Urban Landscape in Southeastern Michigan. J. Fish. Wildl. Manag. 4, 377-385.

55. Dolman, P.M., Waber, K., 2008. Ecosystem and competition impacts of introduced deer. Wildl. Res. 35, 202-214.

56. Durant, S.M., 2000. Living with the enemy: avoidance of hyenas and lions by cheetahs in the Serengeti. Behav. Ecol. 11, 624-632.

57. East, R., 1984. Rainfall, soil nutrient status and biomass of large African savanna mammals. Afr. J. Ecol. 22, 245-270.

58. Eccard, J.A., Liesenjohann, T., 2014. The importance of predation risk and missed opportunity costs for context-dependent foraging patterns. PLOS. ONE. 9, e94107.

59. Eliason, J.J., Berry, W.H., 1994. Effects of militaryauthorized activities on the San Joaquin kit fox at Camp Roberts. Natl. Mil. Fish. Wildlife. T, 4-10. .

60. Elmhagen, B., Ludwig, G., Rushton, S.P., Helle, P., Lindén, H., 2010. Top predators, mesopredators and their prey: interference ecosystems along bioclimatic productivity gradients. J. Anim. Ecol. 79, 785-794.

61. Elmhagen, B., Rushton, S.P., 2007. Trophic control of mesopredators in terrestrial ecosystems: top-down or bottom-up? Ecol. Lett. 10, 197-206. 
62. Erb, P.L., McShea, W.J., Guralnick, R.P., 2012. Anthropogenic Influences on Macro-Level Mammal Occupancy in the Appalachian Trail Corridor. PLOS. ONE. 7, 10.

63. Estes, J., Terborgh, J., Brashares, J., Power, M., Berger, J., Bond, W., Carpenter, S., Essington, T., Holt, R., Jackson, J., Marquis, R., Oksanen, L., Oksanen, T., Paine, R., Pikitch, E., Ripple, W., Sandin, S., Scheffer, M., Schoener, T., Shurin, J., Sinclair, A., Soulé, M., Virtanen, R., Wardle, D., 2011. Trophic downgrading of planet earth. Science. 333, 301-306.

64. Fedriani, J.M., Fuller, T.K., Sauvajot, R.M., York, E.C., 2000. Competition and intraguild predation among three sympatric carnivores. Oecologia. 125, 258-270.

65. Fleming, P.J.S., Allen, B.L., Ballard, G.A., 2012. Seven considerations about dingoes as biodiversity engineers: the socioecological niches of dogs in Australia. Aus. Mammal. 34, 119-131.

66. Ford, A.T., Goheen, J.R., Augustine, D.J., Kinnaird, M.F., O'Brien, T.G., Palmer, T.M., Pringle, R.M., Woodroffe, R., 2015. Recovery of African wild dogs suppresses prey but does not trigger a trophic cascade. Ecology 96, 2705-2714

67. Fortin, D., Beyer, H.L., Boyce, M.S., Smith, D.W., Duchesne, T., Mao, J.S., 2005. Wolves influence elk movements: Behaviour shapes a trophic cascade in Yellowstone National Park. Ecology. 86, 1320-1330.

68. Fortin, D., Fortin, M.E., Beyer, H.L., Duchesne, T., Courant, S., Dancose, K., 2009. Group-sizemediated habitat selection and group fusion-fission dynamics of bison under predation risk. Ecology. 90, 2480-2490.

69. Frid, A., Dill, L., 2002. Human-caused disturbance stimuli as a form of predation risk. Conserv. Ecol. 6, art 11.

70. Fuller, R.J., 2001. Responses of woodland birds to increasing numbers of deer: a review of evidence and mechanisms. Forestry. 74, 289-298.

71. Garrott, R.A., Bruggeman, J.E., Becker, M.S., Kalinowski, S.T., White, P.J., 2007. Evaluating prey switching in wolf-ungulate systems. Ecol. Appl. 17, 1588-1597.

72. Gehrt, S.D., Prange, S., 2007. Interference competition between coyotes and raccoons: a test of the mesopredator release hypothesis. Behav. Ecol. 18, 204-214.

73. George, S.L., Crooks, K.R., 2006. Recreation and large mammal activity in an urban nature reserve. Biol. Conserv. 133, 107-117.

74. Gill, R., 2000. The Impact of Deer on Woodland Biodiversity, pp. 1-6. Forestry Commission, [Online] Available at: http://www.forestry.gov.uk (Accessed:15/06/2012).

75. Glen, A.S., Dickman, C.R., Soule, M.E., Mackey, B.G., 2007. Evaluating the role of the dingo as a trophic regulator in Australian ecosystems. Austral. Ecol. 32, 492-501.

76. Gorman, M.L., Mills, M.G., Raath, J.P., Speakman, J.R., 1998. High hunting costs make African wild dogs vulnerable to kleptoparasitism by hyaenas. Nature. 391, 479-481.

77. Halofsky, J.S., Ripple, W.J., 2008. Fine-scale predation risk on elk after wolf reintroduction in Yellowstone National Park, USA. Oecologia. 155, 869-877.

78. Hanna, E., Cardillo, M., 2014. Island mammal extinctions are determined by interactive effects of life history, island biogeography and mesopredator suppression. Glob. Ecol. Biogeogr. 23, 395-404.

79. Harmsen, B., Foster, R., Silver, S., Ostro, L., Doncaster, C., 2011. Jaguar and puma activity patterns in relation to their main prey. Mamm. Biol. 76, 320-324. 
80. Haskell, D.E., Webster, C.R., Flaspohler, D.J., Meyer, M.W., 2013. Relationship between Carnivore Distribution and Landscape Features in the Northern Highlands Ecological Landscape of Wisconsin. Am. Midl. Nat. 169, 1-16.

81. Hayes, R.D., Baer, A.M., Wotschikowsky, U., Harestad, A.S., 2000. Kill rate by wolves on moose in the Yukon. Can. J. Zool. 78, 49-59.

82. Hayward, M., Slotow, R., 2009. Temporal Partitioning of Activity in Large African Carnivores: Tests of Multiple Hypotheses. S. Afr. J. Wildl. Res. 39, 109-125.

83. Hayward, M.W., 2009. Conservation management for the past, present and future. Biodivers. Conserv. 18, 765-775.

84. Hayward, M.W., 2012. Time to agree on a conservation benchmark for Australia. Pac. Conserv. Biol. 18, 69-76.

85. Hayward, M.W., Hayward, M.D., 2012. Waterhole use by African Fauna. S. Afr. J. Wildl. Res. 42, 117-127.

86. Hayward, M.W., Marlow, N., 2014. Will dingoes really conserve wildlife and can our methods tell? J. Appl. Ecol. 51, 835-838.

87. Hayward, M.W., O'Brien, J., Kerley, G.I.H., 2007. Carrying capacity of large African predators: Predictions and tests. Biol. Conserv. 139, 219-229.

88. Hayward, M.W., Ortmann, S., Kowalczyk, R., 2015. Risk perception by endangered European bison Bison bonasus is context (condition) dependent. Landscape. Ecol. 30, 2079-2093.

89. Hebblewhite, M., Munro, R.H., Merrill, E.H., 2009. Trophic consequences of postfire logging in a wolf-ungulate system. Forest. Ecol. Manag. 257, 1053-1062.

90. Hebblewhite, M., Pletscher, D., Paquet, P., 2002. Elk population dynamics in areas with and without predation by recolonizing wolves in Banff National Park, Alberta. Can. J. Zool. 80, 789-799.

91. Hebblewhite, M., White, C.A., Nietvelt, C.G., Mckenzie, J.A., Hurd, T.E., Fryxell, J.M., Bayley, S.E., Paquet, P.C., 2005. Human activity mediates a trophic cascade caused by wolves. Ecology. 86, 2135-2144.

92. Heithaus, M.R., Wirsing, A.J., Burkholder, D., Thomson, J., Dill, L.M., 2009. Towards a predictive framework for predator risk effects: the interaction of landscape features and prey escape tactics. J. Anim. Ecol. 78, 556-562.

93. Henke, S.E., Bryant, F.C., 1999. Effects of coyote removal on the faunal community in western Texas. J. Wildlife. Manage. 63, 1066-1081.

94. Hester, A., Baillie, G., 1998. Spatial and temporal patterns of heather use by sheep and red deer within natural heather:grass mosaics. J. Appl. Ecol. 35, 772-784.

95. Hibert, F., Calenge, C., Fritz, H., Maillard, D., Bouche, P., Ipavec, A., Convers, A., Ombredane, D., de Visscher, M.N., 2010. Spatial avoidance of invading pastoral cattle by wild ungulates: insights from using point process statistics. Biodivers. Conserv. 19, 2003-2024.

96. Hill, D.A., Lambton, S., Proctor, I., Bullock, I., 1991. Winter bird communities in woodland in the Forest of Dean, England, and some implications of livestock grazing. Bird. Study. 38, 5770.

97. Hollings, T., Jones, M., Mooney, N., McCallum, H., 2014. Trophic Cascades Following the Disease-Induced Decline of an Apex Predator, the Tasmanian Devil. Conserv. Biol. 28, 63-75.

98. Hopcraft, J.G.C., Sinclair, A.R.E., Packer, C., 2005. Planning for success: Serengeti lions seek prey accessibility rather than abundance. J. Anim. Ecol. 74, 559-566. 
99. Iranzo, E.C., Traba, J., Acebes, P., Gonzalez, B.A., Mata, C., Estades, C.F., Malo, J.E., 2013. Niche Segregation between Wild and Domestic Herbivores in Chilean Patagonia. PLOS. ONE. 8,8 .

100. Isvaran, K., 2007. Intraspecific variation in group size in the blackbuck antelope: the roles of habitat structure and forage at different spatial scales. Oecologia. 154, 435-444.

101. Jackson, J.B., Kirby, M.X., Berger, W.H., Bjorndal, K.A., Botsford, L.W., Bourque, B.J., Bradbury, R.H., Cooke, R., Erlandson, J., Estes, J.A., Hughes, T.P., Kidwell, S., Lange, C.B., Lenihan, H.S., Pandolfi, J.M., Peterson, C.H., Steneck, R.S., Tegner, M.J., Warner, R.R., 2001. Historical overfishing and the recent collapse of coastal ecosystems. Science. 293, 629-637.

102. Jayakody, S., Sibbald, A., Gordon, I., Lambin, X., 2008. Red deer Cervus elephus vigilance behaviour differs with habitat and type of human disturbance. Wildlife. Biol. 14, 8191.

103. Johnson, C.N., 2010. Red in tooth and claw: how top predators shape terrestrial ecosystems. J. Anim. Ecol. 79, 723-725.

104. Jędrzejewski, W., Schmidt, K., Theuerkauf, J., Jędrzejewska, B., Selva, N., Zub, K., Szymura, L., 2002. Kill rates and predation by wolves on ungulate populations in białowiezå primeval forest (Poland). Ecology. 83, 1341-1356.

105. Kaczensky, P., Hayes, R.D., Promberger, C., 2005. Effect of raven Corvus corax scavenging on the kill rates of wolf Canis lupus packs. Wildlife. Biol. 11, 101-108.

106. Kamler, J.F., Ballard, W.B., Gilliland, R.L., Lemons, P.R., Mote, K., 2003. Impacts of coyotes on swift foxes in northwestern Texas. J. Wildl. Manage. 67, 317-323.

107. Karanth, K.U., Nichols, J.D., Kumar, N.S., Link, W.A., Hines, J.E., 2004. Tigers and their prey: Predicting carnivore densities from prey abundance. Proc. Natl. Acad. Sci. USA. 101, 4854-4858.

108. Kareiva, P., Watts, S., McDonald, R., Boucher, T., 2007. Domesticated nature: Shaping landscapes and ecosystems for human welfare. Science. 316, 1866-1869.

109. Kauffman, M.J., Brodie, J.F., Jules, E.S., 2010. Are wolves saving Yellowstone's aspen? A landscape-level test of a behaviorally mediated trophic cascade. Ecology. 91, 2742 2755.

110. Kauffman, M.J., Varley, N., Smith, D.W., Stahler, D.R., MacNulty, D.R., Boyce, M.S., 2007. Landscape heterogeneity shapes predation in a newly restored predator-prey system. Ecol. Lett. 10, 690-700.

111. Kay, C.E., 1994. Aboriginal overkill - The role of native americans in structuring western ecosystems. Hum. Nature. Int. Bios. 5, 359-398.

112. Khalil, H., Pasanen-Mortensen, M., Elmhagen, B., 2014. The relationship between wolverine and larger predators, lynx and wolf, in a historical ecosystem context. Oecologia. $175,625-637$.

113. Kilgo, J.C., Labisky, R.F., Fritzen, D.E., 1998. Influences of hunting on the behavior of white-tailed deer: Implications for conservation of the Florida panther. Conserv. Biol. 12, 1359-1364.

114. Kloppers, E.L., St. Clair, C.C., Hurd, T.E., 2005. Predator-Resembling Aversive Conditioning for Managing Habituated Wildlife. Ecol. Soc. 10, art 31.

115. Koehler, G.M., Hornocker, M.G., 1991. Seasonal resource use among mountain lions, bobcats, and coyotes. J. Mammal. 72, 391-396. 
116. Koivisto, E., Pusenius, J., 2006. The effects of weasel proximity on the foraging activity of voles. Ann. Zool. Fenn. 43, 45-51.

117. Kolenosky, G.B., Johnston, D.H., 1967. Radio- tracking timber wolves in Ontario. Am. Zool. 7, 289-303.

118. Kotler, B.P., Gross, J.E., Mitchell, W.A., 1994. Applying patch use to assess aspects of foraging behavior in Nubian ibex. J. Wildlife. Manage. 58, 299-307.

119. Krauze-Gryz, D., Gryz, J.B., Goszczynski, J., Chylarecki, P., Zmihorski, M., 2012. The good, the bad, and the ugly: space use and intraguild interactions among three opportunistic predators-cat (Felis catus), dog (Canis lupus familiaris), and red fox (Vulpes vulpes)-under human pressure. Can. J. Zool. 90, 1402-1413.

120. Kronfeld-Schor, N., Dayan, T., 2003. Partitioning of time as an ecological resource. Annu. Rev. Ecol. Evol. Syst. 34, 153-181.

121. Kuijper, D.P.J., de Kleine, C., Churski, M., van Hooft, P., Bubnicki, J., Jedrzejewska, B., 2013. Landscape of fear in Europe: wolves affect spatial patterns of ungulate browsing in Bialowieza Primeval Forest, Poland. Ecography. 36, 1263-1275.

122. Kusak, J., Haswell, P., 2013. Spatio-temporal distribution of activity and space use among wolves, ungulates and humans in Croatia, In 2013 International Wolf Symposium: Wolves and Humans at the Crossroads. DECC - Duluth Entertainment Convention Center, Duluth, Minnesota.

123. Kusak, J., Skrbinšek, A., Huber, D., 2005. Home ranges, movements, and activity of wolves (Canis lupus) in the Dalmatian part of Dinarids, Croatia. Eur. J. Wildl. Res. 51, 254262.

124. Kusak, J., Špičić, S., Slijepčević, V., Bosnić, S.J., RR., Duvnjak, S., Sindičić, M., Majnarić, D.C., Ž., Huber, Đ., 2012. Health status of red deer and roe deer in Gorski kotar, Croatia. Vet. Arhiv. 82, 59-73.

125. Latham, A.D.M., Latham, M.C., Knopff, K.H., Hebblewhite, M., Boutin, S., 2013. Wolves, white-tailed deer, and beaver: implications of seasonal prey switching for woodland caribou declines. Ecography. 36, 1276-1290.

126. Latham, J., 1999. Interspecific interactions of ungulates in European forests: an overview. For. Ecol. Manage. 120, 13-21.

127. Laundré, J.W., Hernández, L., Altendorf, K.B., 2001. Wolves, elk, and bison: reestablishing the" landscape of fear" in Yellowstone National Park, USA. Can. J. Zool. 79, 1401-1409.

128. Laundré, J.W., Hernández, L., López Medina, P., Campanella, A., López-Portillo, J., González-Romero, A., Grajales-Tam, K.M., Burke, A.M., Gronemeyer, P., Browing, D.M., 2014. The landscape of fear: the missing link to understand top-down and bottom-up controls of prey abundance? Ecology. 95, 1141-1152.

129. Laundré, J.W., Hernández, L., Ripple, W.J., 2010. The landscape of fear: ecological implications of being afraid. Open. Ecol. J. 3, 1-7.

130. Leighton, P., Horrocks, J., Kramer, D., 2010. Conservation and the scarecrow effect: Can human activity benefit threatened species by displacing predators? Biol. Conserv. 143, 2156-2163.

131. Lescureux, N., Linnell, J.D., 2014. Warring brothers: The complex interactions between wolves (Canis lupus) and dogs (Canis familiaris) in a conservation context. Biol. Conserv. 171, 232-245. 
132. Letnic, M., Crowther, M.S., Koch, F., 2009a. Does a top-predator provide an endangered rodent with refuge from an invasive mesopredator? Anim. Conserv. 12, 302312.

133. Letnic, M., Dworjanyn, S.A., 2011. Does a top predator reduce the predatory impact of an invasive mesopredator on an endangered rodent? Ecography. 34, 827-835.

134. Letnic, M., Greenville, A., Denny, E., Dickman, C.R., Tischler, M., Gordon, C., Koch, F., 2011. Does a top predator suppress the abundance of an invasive mesopredator at a continental scale? Global. Ecol. Biogeogr. 20, 343-353.

135. Letnic, M., Koch, F., Gordon, C., Crowther, M.S., Dickman, C.R., 2009b. Keystone effects of an alien top-predator stem extinctions of native mammals. P. Roy. Soc. B. 276, 3249-3256.

136. Levi, T., Wilmers, C.C., 2012. Wolves-coyotes-foxes: a cascade among carnivores. Ecology. 93, 921-929.

137. Lightfoot, K.G., Cuthrell, R.Q., Striplen, C.J., Hylkema, M.G., 2013. Rethinking the study of landscape management practices among hunter-gatherers in North America. Am. Antiq. 78, 285-301

138. Linnell, J.D., Kaczensky, P., Wotschikowsky, U., Lescureux, N., Boitani, L., 2015. Framing the relationship between people and nature in the context of European conservation. Conserv. Biol. 29, 978-985.

139. Linnell, J.D., Strand, O., 2000. Interference interactions, co-existence and conservation of mammalian carnivores. Divers. Distrib. 6, 169-176.

140. Lourenco, R., Penteriani, V., Rabaca, J.E., Korpimaki, E., 2014. Lethal interactions among vertebrate top predators: a review of concepts, assumptions and terminology. Biol. Rev. 89, 270-283.

141. López-Bao, J.V., Kaczensky, P., Linnell, J. D., Boitani, L., Chapron, G., 2015. Carnivore coexistence: wilderness not required. Science. 348, 871.

142. MacNulty, D.R., Smith, D.W., Mech, L.D., Eberly, L.E., 2009. Body size and predatory performance in wolves: is bigger better? J. Anim. Ecol. 78, 532-539.

143. Marshall, K.N., Hobbs, N.T., Cooper, D.J., 2013. Stream hydrology limits recovery of riparian ecosystems after wolf reintroduction. Proc. R. Soc. B. 280.

144. McDonald, R.A., O'Hara, K., Morrish, D.J., 2007. Decline of invasive alien mink (Mustela vison) is concurrent with recovery of native otters (Lutra lutra). Divers. Distrib. 13, 92-98.

145. Mech, L., 2012. Is science in danger of sanctifying the wolf? Biol. Conserv. 150, 143149.

146. Melis, C., Jedrzejewska, B., Apollonio, M., Barton, K.A., Jedrzejewski, W., Linnell, J.D.C., Kojola, I., Kusak, J., Adamic, M., Ciuti, S., Delehan, I., Dykyy, I., Krapinec, K., Mattioli, L., Sagaydak, A., Samchuk, N., Schmidt, K., Shkvyrya, M., Sidorovich, V.E., Zawadzka, B., Zhyla, S., 2009. Predation has a greater impact in less productive environments: variation in roe deer, Capreolus capreolus, population density across Europe. Global. Ecol. Biogeogr. 18, 724-734.

147. Mella, V.S.A., Banks, P.B., McArthur, C., 2014. Negotiating multiple cues of predation risk in a landscape of fear: what scares free-ranging brushtail possums? J. Zool. 294, 22-30. 
148. Miller, B.J., Harlow, H.J., Harlow, T.S., Biggins, D., Ripple, W.J., 2012. Trophic cascades linking wolves (Canis lupus), coyotes (Canis latrans), and small mammals. Can. J. Zool. 90, 70-78.

149. Montgomery, R.A., Vucetich, J.A., Peterson, R.O., Roloff, G.J., Millenbah, K.F., 2013. The influence of winter severity, predation and senescence on moose habitat use. J. Anim. Ecol. 82, 301-309.

150. Muhly, T.B., Alexander, M., Boyce, M.S., Creasey, R., Hebblewhite, M., Paton, D., Pitt, J.A., Musiani, M., 2010. Differential risk effects of wolves on wild versus domestic prey have consequences for conservation. Oikos. 119, 1243-1254.

151. Mukherjee, S., Zelcer, M., Kotler, B.P., 2009. Patch use in time and space for a mesopredator in a risky world. Oecologia. 159, 661-668.

152. Newsome, T.M., Ballard, G.A., Fleming, P.J.S., van de Ven, R., Story, G.L., Dickman, C.R., 2014. Human-resource subsidies alter the dietary preferences of a mammalian top predator. Oecologia. 175, 139-150.

153. Newsome, T.M., Ripple, W.J., 2014. A continental scale trophic cascade from wolves through coyotes to foxes. J. Anim. Ecol. 84, 49-59.

154. Odden, J., Linnell, J.D.C., Andersen, R., 2006. Diet of Eurasian lynx, Lynx lynx, in the boreal forest of southeastern Norway: the relative importance of livestock and hares at low roe deer density. Eur. J. Wildlife. Res. 52, 237-244.

155. Ordiz, A., Bischof, R., Swenson, J.E., 2013. Saving large carnivores, but losing the apex predator? Biol. Conserv. 168, 128-133.

156. Owen-Smith, N., 2014. Spatial ecology of large herbivore populations. Ecography. 37, 416-430.

157. Packer, C., Kosmala, M., Cooley, H.S., Brink, H., Pintea, L., Garshelis, D., Purchase, G., Strauss, M., Swanson, A., Balme, G., Hunter, L., Nowell, K., 2009. Sport Hunting, Predator Control and Conservation of Large Carnivores. PLOS. ONE. 34, 1160-1164.

158. Painter, L.E., Beschta, R.L., Larsen, E.J., Ripple, W.J., 2015. Recovering aspen follow changing elk dynamics in Yellowstone: evidence of a trophic cascade? Ecology. 96, 252-263.

159. Palomares, F., Caro, T., 1999. Interspecific killing among mammalian carnivores. Amer. Nat. 153, 492-508.

160. Panzacchi, M., Linnell, J.D.C., Serrao, G., Eie, S., Odden, M., Odden, J., Andersen, R., 2008. Evaluation of the importance of roe deer fawns in the spring-summer diet of red foxes in southeastern Norway. Ecol. Res. 23, 889-896.

161. Paquet, P.C., Darimont, C.T., 2010. Wildlife conservation and animal welfare: two sides of the same coin? Anim. Welf. 19, 177-190.

162. Parks, S.A., Harcourt, A.H., 2002. Reserve size, local human density, and mammalian extinctions in US protected areas. Conserv. Biol. 16, 800-808.

163. Peckarsky, B.L., Abrams, P.A., Bolnick, D.I., Dill, L.M., Grabowski, J.H., Luttbeg, B., Orrock, J.L., Peacor, S.D., Preisser, E.L., Schmitz, O.J., Trussell, G.C., 2008. Revisiting the classics: Considering nonconsumptive effects in textbook examples of predator-prey interactions. Ecology. 89, 2416-2425.

164. Pelletier, F., 2006. Effects of tourist activities on ungulate behaviour in a mountain protected area. J. Mt. Ecol. 8, 15-19.

165. Polis, G.A., Sears, A.L.W., Huxel, G.R., Strong, D.R., Maron, J., 2000. When is a trophic cascade a trophic cascade? Trends. Ecol. Evol. 15, 473-475. 
166. Post, E., Peterson, R.O., Stenseth, N.C., McLaren, B.E., 1999. Ecosystem consequences of wolf behavioural response to climate. Nature. 401, 905-907.

167. Prange, S., Gehrt, S.D., 2007. Response of skunks to a simulated increase in coyote activity. J. Mammal. 88, 1040-1049.

168. Proffitt, K.M., Gude, J.A., Hamlin, K.L., Messer, M.A., 2013. Effects of hunter access and habitat security on elk habitat selection in landscapes with a public and private land matrix. J. Wildlife. Manage. 77, 514-524.

169. Prugh, L.R., Stoner, C.J., Epps, C.W., Bean, W.T., Ripple, W.J., Laliberte, A.S., Brashares, J.S., 2009. The rise of the mesopredator. Bioscience. 59, 779-791.

170. Ralls, K., White, P.J., 1995. Predation on San Joaquin kit foxes by larger canids. J. Mammal. 76, 723-729.

171. Rayner, M.J., Hauber, M.E., Imber, M.J., Stamp, R.K., Clout, M.N., 2007. Spatial heterogeneity of mesopredator release within an oceanic island system. P. Natl. Acad. Sci. USA. 104, 20862-20865.

172. Reimoser, F., 2003. Steering the impacts of ungulates on temperate forests. J. Nat. Conser. 10, 243-252.

173. Reimoser, F., Armstrongb, H., Suchantc, R., 1999. Measuring forest damage of ungulates: what should be considered. Forest. Ecol. Manag. 120, 47-58.

174. Ripple, W., Beschta, R., 2004. Wolves and the ecology of fear: Can predation risk structure ecosystems? Bioscience. 54, 755-766.

175. Ripple, W.J., Estes, J.A., Beschta, R.L., Wilmers, C.C., Ritchie, E.G., Hebblewhite, M., Berger, J., Elmhagen, B., Letnic, M., Nelson, M.P., Schmitz, O.J., Smith, D.W., Wallach, A.D., Wirsing, A.J., 2014. Status and Ecological Effects of the World's Largest Carnivores. Science. $343,1241484$.

176. Ripple, W.J., Larsen, E.J., 2000. Historic aspen recruitment, elk, and wolves in northern Yellowstone National Park, USA. Biol. Conserv. 95, 361-370.

177. Ripple, W.J., Larsen, E.J., Renkin, R.A., Smith, D.W., 2001. Trophic cascades among wolves, elk and aspen on Yellowstone National Park's northern range. Biol. Conserv. 102, 227-234.

178. Ripple, W.J., Wirsing, A.J., Wilmers, C.C., Letnic, M., 2013. Widespread mesopredator effects after wolf extirpation. Biol. Conserv. 160, 70-79.

179. Ritchie, E.G., Elmhagen, B., Glen, A.S., Letnic, M., Ludwig, G., McDonald, R.A., 2012. Ecosystem restoration with teeth: what role for predators? Trends. Ecol. Evol. 27, 265-271.

180. Ritchie, E.G., Johnson, C., N., 2009. Predator interactions, mesopredator release and biodiversity conservation. Ecol. Lett. 12, 982-998.

181. Rodewald, A.D., Kearns, L.J., Shustack, D.P., 2011. Anthropogenic resource subsidies decouple predator-prey relationships. Ecol. Appl. 21, 936-943.

182. Roemer, G.W., Gompper, M.E., Valkengurgh, B.V., 2009. The ecological role of the mammalian mesocarnivore. Bioscience. 59, 165-173.

183. Rogala, J.K., Hebblewhite, M., Whittington, J., White, C.A., Coleshill, J., Musiani, M., 2011. Human Activity Differentially Redistributes Large Mammals in the Canadian Rockies National Parks. Ecol. Soc. 16, 24.

184. Rolston, H., 2001. Natural and unnatural; Wild and cultural. West. N. Am. Nat. 61, 267-276. 
185. Ruiz-Capillas, P., Mata, C., Malo, J.E., 2013. Community Response of Mammalian Predators and Their Prey to Motorways: Implications for Predator-Prey Dynamics. Ecosystems. 16, 617-626.

186. Russell, A.J.M., Storch, I., 2004. Summer food of sympatric red fox and pine marten in the German Alps. Eur. J. Wildl. Res. 50, 53-58.

187. Samelius, G., Andren, H., Kjellander, P., Liberg, O., 2013. Habitat Selection and Risk of Predation: Re-colonization by Lynx had Limited Impact on Habitat Selection by Roe Deer PLOS. ONE. 8, 1-8.

188. Sand, H., Wikenros, C., Wabakken, P., Liberg, O., 2006. Cross-continental differences in patterns of predation: will naive moose in Scandinavia ever learn? Proc. R. Soc. B. 273, 1421-1427.

189. Sanford, E., 1999. Regulation of keystone predation by small changes in ocean temperature. Science. 283, 2095-2097.

190. Sargeant, A.B., Allen, S.H., Eberhardt, R.T., 1984. Red fox predation on breeding ducks in midcontinent North America. Wildlife. Monogr. 89, 3-41.

191. Schmitz, O.J., Hamback, P.A., Beckerman, A.P., 2000. Trophic cascades in terrestrial systems: A review of the effects of carnivore removals on plants. Am. Nat. 155, 141-153.

192. Schuette, P., Wagner, A.P., Wagner, M.E., Creel, S., 2013. Occupancy patterns and niche partitioning within a diverse carnivore community exposed to anthropogenic pressures. Biol. Conserv. 158, 301-312.

193. Selva, N., Berezowska-Cnota, T., Elguero-Claramunt, I., 2014. Unforeseen Effects of Supplementary Feeding: Ungulate Baiting Sites as Hotspots for Ground-Nest Predation. PLOS. ONE. 9, e90740.

194. Selås, V., Vik, J.O., 2006. Possible impact of snow depth and ungulate carcasses on red fox (Vulpes vulpes) populations in Norway, 1897-1976. J. Zool. 269, 299-308.

195. Semeniuk, C.A.D., Musiani, M., Birkigt, D.A., Hebblewhite, M., Grindal, S., Marceau, D.J., 2014. Identifying non-independent anthropogenic risks using a behavioral individualbased model. Ecol. Complexity. 17, 67-78.

196. Sibbald, A., Hooper, R., McLeod, J., Gordon, I., 2011. Responses of red deer (Cervus elaphus) to regular disturbance by hill walkers. Eur. J. Wildlife. Res. 57, 817-825.

197. Sidorovich, V.E., Tikhomirova, L.L., Jedrzejewska, B., 2003. Wolf Canis lupus numbers, diet and damage to livestock in relation to hunting and ungulate abundance in northeastern Belarus during 1990-2000. Wildlife. Biol. 9, 103-111.

198. Sih, A., Englund, G., Wooster, D., 1998. Emergent impacts of multiple predators on prey. Trends. Ecol. Evol. 13, 350-355.

199. Soulé, M.E., Bolger, D.T., Alberts, A.C., Wrights, J., Sorice, M., Hill, S., 1988. Reconstructed dynamics of rapid extinctions of chaparral-requiring birds in urban habitat islands. Conserv. Biol. 2, 75-92.

200. Sovada, M.A., Sargeant, A.B., Grier, J.W., 1995. Differential effects of coyotes and red foxes on duck nest success. J. Wildlife. Manage. 59, 1-9.

201. Standley, W.G., Berry, W.H., O'Farrell, T.P., Kato, T.T., 1992. Mortality of San Joaquin kit fox (Vulpes velox macrotis) at Camp Roberts Army National Guard Training Site, California. EG and G Energy Measurements, Inc., Goleta, CA (United States). Santa Barbara Operations. 
202. Strong, D.R., 1992. Are trophic cascades all wet? Differentiation and donor-control in speciose ecosystems. Ecology. 73, 747-754.

203. Sutherland, W.J., Freckleton, R.P., Godfray, H.C.J., Beissinger, S.R., Benton, T., Cameron, D.D., Carmel, Y., Coomes, D.A., Coulson, T., Emmerson, M.C., Hails, R.S., Hays, G.C., Hodgson, D.J., Hutchings, M.J., Johnson, D., Jones, J.P.G., Keeling, M.J., Kokko, H., Kunin, W.E., Lambin, X., Lewis, O.T., Malhi, Y., Mieszkowska, N., Milner-Gulland, E.J., Norris, K., Phillimore, A.B., Purves, D.W., Reid, J.M., Reuman, D.C., Thompson, K., Travis, J.M.J., Turnbull, L.A., Wardle, D.A., Wiegand, T., 2013. Identification of 100 fundamental ecological questions. J. Ecol. 101, 58-67.

204. Terborgh, J., Lopez, L., Nunez, P., Rao, M., Shahabuddin, G., Orihuela, G., Riveros, M., Ascanio, R., Adler, G.H., Lambert, T.D., Balbas, L., 2001. Ecological meltdown in predator-free forest fragments. Science. 294, 1923-1926.

205. Theuerkauf, J., 2009. What drives wolves: Fear or hunger? Humans, diet, climate and wolf activity patterns. Ethology. 115, 649-657.

206. Theuerkauf, J., Gula, R., Pirga, B., Tsunoda, H., Eggermann, J., Brzezowska, B., Rouys, S., Radler, S., 2007. Human impact on wolf activity in the Bieszczady Mountains, SE Poland. Ann. Zool. Fennici. 44, 225-231.

207. Theuerkauf, J., Jędrzejewski, W., Schmidt, K., Okarma, H., Ruczyński, I., Śnieżko, S., Gula, R., 2003. Daily patterns and duration of wolf activity in the Białowieża forest Poland. J. Mammal. 84, 243-253.

208. Thurber, J., Peterson, R.O., Woolington, J.D., Vucetich, J.A., 1992. Coyote coexistence with wolves on the Kenai Peninsula, Alaska. Can. J. Zool. 70, 2494-2498.

209. Trewby, I., Wilson, G., Delahay, R., Walker, N., Young, R., Davison, J., Cheeseman, C., Robertson, P., Gorman, M., McDonald, R., 2008. Experimental evidence of competitive release in sympatric carnivores. Biol. Lett. 4, 170-172.

210. Tschöpe, O., Wallschläger, D., Burkart, M., Tielbörger, K., 2011. Managing open habitats by wild ungulate browsing and grazing: A case-study in North-Eastern Germany. Appl. Veg. Sci. 14, 200-209.

211. Valkenburgh, B.V., Hayward, M.W., Ripple, W.J., Meloro, C., Roth, V.L., 2015. The Impact of Large Terrestrial Carnivores on Pleistocene Ecosystems. P. Natl. Acad. Sci. USA. In review.

212. Van Dyk, G., Slotow, R., 2003. The effects of fences and lions on the ecology of African wild dogs reintroduced to Pilanesberg National Park, South Africa. Afr. Zool. 38, 7994.

213. Van Orsdol, K.G., Hanby, J.P., Bygott, J.D., 1985. Ecological correlates of lion social organization (Panthera leo). J. Zool. 206, 97-112.

214. Virgos, E., Travaini, A., 2005. Relationship between small-game hunting and carnivore diversity in central Spain. Biodivers. Conserv. 14, 3475-3486.

215. Wang, B., Yang, X.L., 2015. Seed removal by scatter-hoarding rodents: The effects of tannin and nutrient concentration. Behav. Processes. 113, 94-98.

216. Whittington, J., St Clair, C.C., Mercer, G., 2005. Spatial responses of wolves to roads and trails in mountain valleys. Ecol. Appl. 15, 543-553.

217. Willems, E.P., Hill, R.A., 2009. Predator-specific landscapes of fear and resource distribution: effects on spatial range use. Ecology. 90, 546-555. 
218. Wilmers, C.C., Getz, W.M., 2005. Gray Wolves as Climate Change Buffers in Yellowstone. PLOS. Biol. 3, 571-576.

219. Wilmers, C.C., Post, E., Peterson, R.O., Vucetich, J.A., 2006. Predator disease outbreak modulates top-down, bottom-up and climatic effects on herbivore population dynamics. Ecol Lett 9, 383-389.

220. Winnie, J., 2014. Predation risk, elk, and aspen: reply. Ecology. 95, 2671-2674.

221. Winnie, J.A., 2012. Predation risk, elk, and aspen: tests of a behaviorally mediated trophic cascade in the Greater Yellowstone Ecosystem. Ecology. 93, 2600-2614.

222. Wirsing, A.J., Cameron, K.E., Heithaus, M.R., 2010. Spatial responses to predators vary with prey escape mode. Anim. Behav. 79, 531-537.

223. Wolff, J.O., Horn, T.V., 2003. Vigilance and foraging patterns of American elk during the rut in habitats with and without predators. Can. J. Zool. 81, 266-271.

224. Yi, X.F., Wang, Z.Y., 2015. Context-dependent seed dispersal determines acorn survival of sympatric oak species. Plant. Ecol. 216, 123-132.

225. Zamora, R., Matias, L., 2014. Seed Dispersers, Seed Predators, and Browsers Act Synergistically as Biotic Filters in a Mosaic Landscape. PLOS. ONE. 9, 8. 


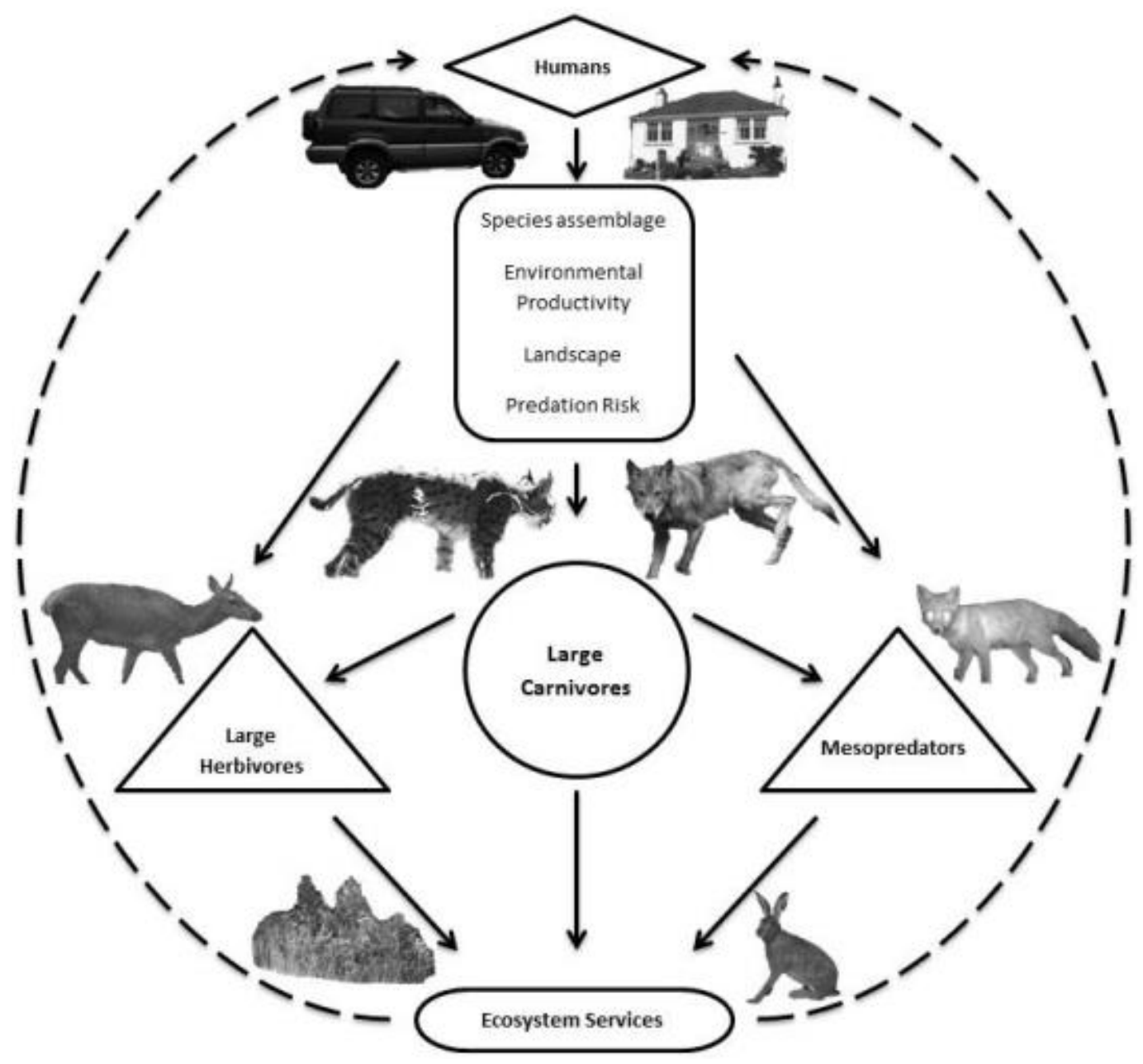

Fig.1. Benefits derived from large carnivores could be dependent on human context. As the most dominant landscape and resource user on the planet, humans have the potential to influence ecosystems and the organisms that inhabit them. The impacts of humans on other species in a given context could alter the direction or severity of consumptive and non-consumptive interactions between species. Humans can affect top down control from large carnivores which can have trickle down effects through trophic interactions, affecting habitat use and foraging behaviour with consequences for ecosystem services (solid arrows). These services can in-turn feedback to affect humans (dashed arrows). This figure represents a simplified flow diagram of how context affects the impacts from large carnivores; additional mechanisms have been excluded for clarity.

Table.1. Human impacts and their potential consequences to trophic systems. Both direct influences and consequent alterations to interspecific interactions can affect ecological processes. The positive $(+)$, negative (-) or neutral (=) impacts of human interventions on a guild of organisms are likely to vary dramatically and will be dependent on context. Human interactions with apex predators can alter mesopredator release (MR), large herbivore release (LHR), predation (P), competition (C), food availability (F), seed predation (SP) and seed dispersal (SD). Negative human influences on large carnivores can release those species they suppress. This could in turn have cascading effects, potentially increasing $(\uparrow)$ or decreasing $(\downarrow)$ pressure on other species further down the food chain. 


\begin{tabular}{|c|c|c|c|c|c|}
\hline $\begin{array}{l}\text { Human-wildlife } \\
\text { interaction }\end{array}$ & $\begin{array}{c}\text { Large } \\
\text { Carnivores }\end{array}$ & $\begin{array}{c}\text { Large } \\
\text { herbivores }\end{array}$ & Mesopredators & $\begin{array}{c}\text { Small } \\
\text { herbivores }\end{array}$ & Vegetation \\
\hline $\begin{array}{c}\text { Hunting Large } \\
\text { Carnivores }\end{array}$ & $-(\uparrow \mathrm{P})$ & $\begin{array}{c}-(\uparrow \mathrm{P} \text { of } \\
\text { young, MR }) \\
+(\text { adults } \downarrow \mathrm{P})\end{array}$ & $\begin{array}{c}+(\downarrow \mathrm{C}) \\
-(\downarrow \text { consistency } \\
\text { of } \mathrm{F}, \text { scavenging })\end{array}$ & $-(\uparrow \mathrm{P}, \mathrm{MR})$ & $\begin{array}{l}-(\uparrow \mathrm{P}, \mathrm{LHR}) \\
-(\downarrow \mathrm{SD}, \mathrm{MR}) \\
+(\downarrow \mathrm{SP})\end{array}$ \\
\hline $\begin{array}{c}\text { Hunting large } \\
\text { herbivores }\end{array}$ & $-(\downarrow F)$ & $-(\uparrow \mathrm{P})$ & $\begin{array}{l}-(\downarrow \mathrm{F}, \\
\text { scavenging \& } \\
\text { young } \\
\text { herbivores }) \\
+(\downarrow \mathrm{C})\end{array}$ & $\begin{array}{l}-(\uparrow \mathrm{P}, \mathrm{MR}) \\
+(\downarrow \mathrm{P}, \downarrow \mathrm{C})\end{array}$ & $\begin{array}{c}-(\downarrow \mathrm{SD}, \mathrm{MR}) \\
-(\uparrow \mathrm{SP}, \mathrm{MR}) \\
\quad+(\downarrow \mathrm{P}) \\
+(\uparrow \mathrm{SD}) \\
\quad+(\downarrow \mathrm{SP})\end{array}$ \\
\hline Alien predators & 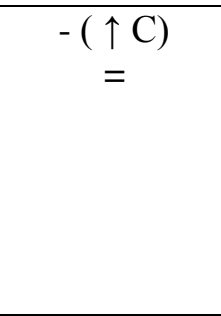 & $\begin{array}{l}-(\uparrow \mathrm{P}) \\
= \\
+(\downarrow \mathrm{P})\end{array}$ & $\begin{array}{c}-(\uparrow \mathrm{C}) \\
= \\
+(\downarrow \mathrm{C})\end{array}$ & $\begin{array}{c}-(\uparrow \mathrm{P}, \mathrm{MR}) \\
= \\
+(\downarrow \mathrm{P}, \downarrow \mathrm{C})\end{array}$ & $\begin{array}{c}-(\uparrow \mathrm{P}, \mathrm{LHR}) \\
-(\downarrow \mathrm{SD}, \mathrm{MR}) \\
-(\uparrow \mathrm{SP}, \mathrm{MR}) \\
= \\
+(\downarrow \mathrm{P}) \\
+(\uparrow \mathrm{SD}) \\
+(\downarrow \mathrm{SP})\end{array}$ \\
\hline $\begin{array}{c}\text { Alien } \\
\text { herbivores }\end{array}$ & $\begin{array}{c}-(\downarrow F) \\
= \\
+(\uparrow F)\end{array}$ & $\begin{array}{l}-(\uparrow \mathrm{C}) \\
= \\
+(\downarrow \mathrm{P})\end{array}$ & $\begin{array}{l}-(\uparrow \mathrm{C}) \\
\quad= \\
+(\downarrow \mathrm{C}) \\
+(\uparrow \mathrm{F})\end{array}$ & $\begin{array}{l}-(\uparrow \mathrm{C}) \\
= \\
+(\downarrow \mathrm{P})\end{array}$ & $\begin{array}{c}-(\uparrow \mathrm{P}) \\
-(\downarrow \mathrm{SD}, \mathrm{MR}) \\
-(\uparrow \mathrm{SP}, \mathrm{MR}) \\
= \\
+(\downarrow \mathrm{P}) \\
+(\uparrow \mathrm{SD}) \\
+(\downarrow \mathrm{SP}) \\
\end{array}$ \\
\hline $\begin{array}{c}\text { Food } \\
\text { provisioning } \\
\text { (predators) }\end{array}$ & $+(\uparrow \mathrm{F})$ & $\begin{array}{l}-(\uparrow \mathrm{P}) \\
\quad= \\
+(\downarrow \mathrm{P})\end{array}$ & $\begin{array}{l}-(\uparrow \mathrm{C}) \\
+(\uparrow \mathrm{F}) \\
+(\downarrow \mathrm{C})\end{array}$ & $\begin{array}{l}-(\uparrow \mathrm{P}, \mathrm{MR}) \\
\quad+(\uparrow \mathrm{F}) \\
\quad+(\downarrow \mathrm{P})\end{array}$ & $\begin{array}{c}-(\downarrow \mathrm{SD}, \mathrm{MR}) \\
-(\uparrow \mathrm{SP}, \mathrm{MR}) \\
\quad+(\downarrow \mathrm{P}) \\
+(\uparrow \mathrm{SD}) \\
\quad+(\downarrow \mathrm{SP}) \\
\end{array}$ \\
\hline $\begin{array}{c}\text { Food } \\
\text { Provisioning } \\
\text { (herbivores) }\end{array}$ & $+(\uparrow \mathrm{F})$ & $+(\uparrow \mathrm{F})$ & $\begin{array}{l}-(\uparrow C) \\
+(\uparrow F)\end{array}$ & $\begin{array}{l}-(\uparrow \mathrm{P}) \\
+(\downarrow \mathrm{P}) \\
+(\uparrow \mathrm{F})\end{array}$ & $\begin{array}{c}-(\uparrow \mathrm{P}) \\
-(\downarrow \mathrm{SD}) \\
-(\uparrow \mathrm{SP}) \\
= \\
+(\downarrow \mathrm{P}) \\
+(\uparrow \mathrm{SD}) \\
+(\downarrow \mathrm{SP}) \\
\end{array}$ \\
\hline Habitat loss & - & - & - & - & - \\
\hline $\begin{array}{c}\text { Habitat } \\
\text { fragmentation }\end{array}$ & - & $\begin{array}{c}- \\
+(\downarrow \mathrm{P})\end{array}$ & $+(\downarrow C)$ & $\begin{array}{c}- \\
-(\uparrow \mathrm{P}, \mathrm{MR}) \\
\quad+(\downarrow \mathrm{P})\end{array}$ & $\begin{array}{c}- \\
-(\uparrow \mathrm{P}) \\
-(\downarrow \mathrm{SD}) \\
-(\uparrow \mathrm{SP}) \\
+(\uparrow \mathrm{SD}) \\
+(\downarrow \mathrm{SP})\end{array}$ \\
\hline $\begin{array}{c}\text { Disturbance } \\
\text { (risk) }\end{array}$ & $\begin{array}{r}- \\
+(\uparrow F)\end{array}$ & $\begin{array}{c}- \\
-(\uparrow \mathrm{P}) \\
+(\downarrow \mathrm{P})\end{array}$ & $\begin{array}{c}- \\
-(\uparrow \mathrm{C}) \\
+(\downarrow \mathrm{C})\end{array}$ & $\begin{array}{c}- \\
-(\uparrow \mathrm{P}) \\
+(\downarrow \mathrm{P})\end{array}$ & $\begin{array}{c}-(\uparrow \mathrm{P}) \\
-(\downarrow \mathrm{SD}) \\
-(\uparrow \mathrm{SP}) \\
= \\
+(\downarrow \mathrm{P}) \\
+(\uparrow \mathrm{SD}) \\
+(\downarrow \mathrm{SP})\end{array}$ \\
\hline
\end{tabular}

